\title{
PENGARUH SUMBER DAYA MANUSIA DAN LINGKUNGAN WIRAUSAHA TERHADAP UPAYA MENGURANGI PENGANGGURAN DI KABUPATEN GOWA
}

\author{
Andi Widiawati*) \\ Dosen STIE Nobel Indonesia Makassar \\ E-mail: widiawati@stienobel-indonesia.ac.id
}

\begin{abstract}
Abstrak
UMKM di Kabupaten Gowa mengalami peningkatan dibanding tahun sebelumnya. Meskipun demikian, peningkatan jumlah tersebut belum tentu diikuti dengan keberhasilan usaha. Untuk itu, perlu diketahui faktor-faktor apa saja yang mempengaruhi kinerja UMKM. Penelitian ini bertujuan untuk mengetahui pengaruh faktor-faktor terhadap kinerja UMKM. Tipe penelitian yang digunakan adalah Deskriptif. Metode analisis yang digunakan adalah analisis Deskriptif kualitatif, yakni analisis data sekunder, yakni data yang diperoleh dari Jurnal ilmiah, Dokumen, buku, artikel serta Internet.

Hasil pembahasan menunjukan karakteristik SDM, karakteristik Lingkungan, Karakteristik Wirausaha dan Pengangguran memiliki tingkat hubungan dan berpengaruh positif terhadap kinerja UMKM. Disarankan UMKM untuk senantiasa melakukan Peningkatkan kualitas, memperhatikan lingkungan untuk menambah pengalaman, konsisten dalam menjalankan usaha, meningkatkan peralatan serta kemauan untuk menggunakan teknologi baru.
\end{abstract}

Kata kunci: Karakteristik SDM, Karakteristik Lingkungan, Karakteristik Pengangguran Wirausaha, UMKM.

\begin{abstract}
Abstrack
MSMEs in Gowa Regency have increased compared to the previous year. Nevertheless, the increase in the number is not necessarily followed by business success. For this reason, it is important to know what factors influence MSME performance. This study aims to determine the effect of factors on MSME performance. The type of research used is descriptive. The analytical method used is qualitative descriptive analysis, namely secondary data analysis, namely data obtained from scientific journals, documents, books, articles and the Internet.

The results of the discussion showed the characteristics of human resources, environmental characteristics, entrepreneurial characteristics and unemployment have a relationship level and have a positive effect on the performance of MSMEs. It is recommended that MSMEs always improve quality, pay attention to the environment to add experience, be consistent in running a business, improve equipment and the willingness to use new technology.
\end{abstract}

Keywords: HR Characteristics, Environmental Characteristics, Unemployment Characteristics, Entrepreneurship, MSME

\section{PENDAHULUAN}

Pengangguran adalah suatu keadaan di mana seseorang yang tergolong dalam angkatan kerja ingin mendapatkan pekerjaan tetapi belum dapat memperolehnya (Sadon Sukirno, 2000). Seseorang yang tidak bekerja, tetapi tidak secara aktif mencari pekerjaan tidak tergolong sebagai penganggur. Dewasa ini jumlah pengangguran di Indonesia masih cukup tinggi. Indikator yang biasa digunakan untuk mengukur pengangguran adalah Tingkat Pengangguran Terbuka (TPT). 
Tingkat Pengangguran Terbuka (TPT) umumnya didefinisikan secara konvensional sebagai proporsi angkatan kerja yang tidak bekerja dan mencari pekerjaan.

Ukuran ini dapat digunakan untuk mengindikasikan seberapa besar penawaran kerja yang tidak dapat terserap dalam pasar kerja di sebuah negara atau wilayah. Jumlah pengangguran secara nasional ini tentu saja dipengaruhi dengan jumlah pengangguran di daerah baik itu di perkotaan maupun di perdesaan. Ketersediaan lapangan kerja yang relatif terbatas, tidak mampu menyerap para pencari kerja yang senantiasa bertambah setiap tahun seiring dengan bertambahnya jumlah penduduk. Tingginya angka pengangguran tidak hanya menimbulkan masalah masalah di bidang ekonomi, melainkan juga berbagai masalah di bidang sosial, seperti kemiskinan dan kerawanan sosial.

Sementara pemerintah belum mampu mengimbangi dengan penyediakan lapangan pekerjaan. Oleh karena itu, masyarakat perlu merubah mindsetnya agar tidak lagi menjadi pencari kerja, tetapi ikut berperan serta menjadi penyedia lapangan kerja baik bagi dirinya sendiri maupun bagi masyarakat luas. Menjadi wirausaha merupakan solusi menuju kemandirian bangsa. Berbicara tentang wirausaha maka kita tidak bisa memisahkan dengan UMKM. Perkembangan UMKM dari tahun ke tahun menunjukkan tren yang meningkat. Hal ini tidak terlepas dari peran Pemerintah dalam mengimplementasikan kebijakan yang mendorong tumbuh dan berkembangnya skala usaha mikro, kecil dan menengah (UMKM).

Berdasarkan fenomena-fenomena yang telah dikemukakan sebelumnya, penulisan makalah ini berusaha merumuskan masalah "Sejauhmana Karakteristik Sumber Daya Manusia (SDM) dan Dinamika Lingkungan Berpengaruh Terhadap Kewirausahaan dan UMKM di Kabupaten Gowa.

\section{Tujuan Penelitian}

Dalam penulisan makalah ini, maka tujuan yang ingin dicapai adalah untuk mengetahui karakteristik sumberdaya manusia dan dinamika lingkungan berpengaruh terhadap kewirausahaan dan UMKM di Kabupaten Gowa.

\section{Kajian Teoritis Karakteristik Wirausaha \\ Karakteristik UMKM di Indonesia, berdasarkan penelitian yang dilakukan oleh AKATIGA, the Center for Micro and Small Enterprise Dynamic} (CEMSED), dan the Center for Economic and Social Studies (CESS) pada tahun 2000 adalah mempunyai daya tahan untuk hidup dan mempunyai kemampuan untuk meningkatkan kinerjanya selama krisis ekonomi. Hal ini disebabkan oleh fleksibilitas UMKM dalam melakukan penyesuaian proses produksinya, mampu berkembang dengan modal sendiri, mampu mengembalikan pinjaman dengan bunga tinggi dan tidak terlalu terlibat dalam hal birokrasi.

\section{Kajian Teoritis Dinamika Lingkungan}

Menurut Philip Kotler (1997) dalam Pandji Anoraga; Manajemen Bisnis, 2004: perusahaan, para pemasok, para perantara pemasaran, para pelanggan, pesaing dan lapisan masyarakat, semua menjalankan fungsinya dalam kekuatan lingkungan makro yang lebih besar dan dalam kecenderungan-kecenderungan yang sangat besar, membentuk berbagai peluang dan memberikan ancaman terhadap perusahaan. Lingkungan makro perusahaan terdiri dari enam 
kekuatan utama yaitu kependudukan, ekonomi, fisik, teknologi, politik/hukum, dan sosial/budaya.

\section{Kajian Teoritis Kompetensi SDM}

Penelitian Porter dalam Pandji Anoraga; Manajemen Bisnis, 2004: keunggulan bersaing negara-negara maju mencakup tersedianya peranan sumber daya dan melihat lebih jauh pada keadaan negara yang mempengaruhi daya saing perusahaan-perusahaan internasional pada industri yang berbeda. Hal yang penting dari penelitian Porter adalah pengakuannya bahwa sebagian besar sumber daya yang penting, antara lain: keahlian tenaga kerja yang tinggi, teknologi dan sistem manajemen yang canggih diciptakan melalui investasi oleh orang-orang dan perusahaanperusahaan.

\section{Kajian Teoritis Usaha Mikro, Kecil dan Menengah}

Kewirausahaan pada dasarnya tidak selalu identik dengan usaha mikro, kecil dan menengah namun sejak lama kewirausahaan dianggap sebagai faktor pendorong utama dibalik pertumbuhan ekonomi di berbagai Negara. Menurut Stoner et.al (1995), bentuk usaha yang sesuai bagi wirausaha adalah usaha kecil karena umumnya memiliki beberapa pekerja sehingga memudahkan wirausaha mengorganisasikan usahanya. Kinerja UMKM sebagai tingkat pencapaian atau prestasi dari perusahaan dalam periode waktu tertentu dengan indikator: peningkatan volume penjualan, peningkatan jumlah pegawai dan profitabilitas usaha.

\section{Alur Pikir}

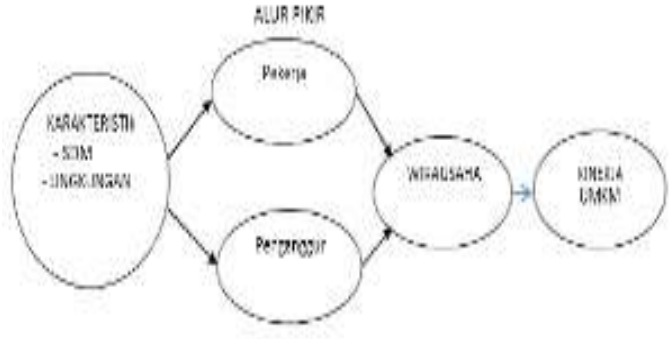

\section{SUMBER DATA}

Dalam penyusunan karya tulis ini data yang digunakan bersumber dari data sekunder, yakni data yang diperoleh dari Jurnal ilmiah, Dokumen, buku, artikel serta Internet.

\section{Analisa data dan Lokasi}

Dalam menganalisis data yang diperoleh dari sumber data, metode penelitian yang dipergunakan adalah metode analisa deskriptif kualitatif.

Lokasi yang menjadi objek penelitian adalah berada di Kabupaten Gowa Sulawesi Selatan.

\section{HASIL DAN PEMBAHASAN}

Prestasi yang dicapai Kabupaten Gowa sebagaimana yang digambarkan terdahulu tidak terlepas dari dukungan karakteristik sumber daya manusia (SDM) dan lingkungan yang dimiliki oleh Kabupaten Gowa yang berdampak pada meningkatnya kegiatan ekonomi yang dapat dilihat dari pertumbuhan wirausaha dan UMKM dari tahun ketahun, pada tahun 2016 sebanyak 6.297 unit dan meningkat pada tahun 2017 menjadi 6.936 unit.

\section{Karakteristik Sumber Daya Manusia (SDM)}

Karakteristik Sumber Daya Manusia (SDM) yang berperan dalam meningkatnya kegiaatan UMKM adalah sumber daya Manusia yang memiliki pendidikan, usia kerja, ketetampilan, keahlian. Sumber Daya Manusia yang dimiliki oleh Kabupaten Gowa dilihat dari Tingkat pendidikan tahun 2017, adalah : Tingkat SD sebanyak 130.013, 
tingkat SLTP sebanyak 60.544, tingkat SLTA sebanyak 61.447, tingkat D1, D2, D3/Akademi sebanyak 3.137 dan Tingkat Sarjana S1, S2, S3 sebanyak 39.577.

Dan jumlah usia kerja yang ada di Kabupaten Gowa adalah sebanyak 312.726.

Jumlah penduduk yang bekerja berdasarkan sector lapangan pekerjaan menurut keahlian /keterampilan adalah :

- Pertanian, kehutanan, perikanan sebanyak 97.670

- Industri pengolahan sebanyak 38.031

- Perdagangan besar, eceran, rumah makan dan hotel sebanyak 69.809

- Jasa kemasyarakatan, social dan perorangan sebanyak 52.340

- Lainnya sebanyak 54.876

\section{Karakteristik Lingkungan}

Dalam karakteristik lingkungan termasuk didalamnya yang meliputi, Kependudukan, Ekonomi, Fisik, teknologi, Politik/Hukum dan Sosial Budaya.

1. Secara total jumlah penduduk Kabupaten Gowa tahun 2017 menunjukkan jumlah sebanyak 748.200 ini merupakan potensi besar bagi berkembangnya perekonomian Kabupaten Gowa ke depan.

2. Ekonomi Kabupaten Gowa secara keseluruhan menunjukan pertumbuhan pluktuatif dari tahun ke tahun dimana laju pertumbuhan ekonomi pada tahun 2015 sebanyak 6,80\%, dan di tahun 2016 naik menjadi 7,63 \% dan tahun 2017 turun menjadi $7,51 \%$.

3. Fisik termasuk didalamnya Sarana dan Prasarana ekonomi, yang meliputi tersedianya tenaga listrik, tersedianya sarana telekomunikasi berupa telepon, sarana jalan, perbankan serta pasar. Kesemua sarana dan prasaran tersebut sudah menjangkau keseluruh pelosok di Kabupaten Gowa.

4. Teknologi adalah keseluruhan sarana untuk menyediakan barang barang yang diperlukan bagi kelangsungan dan kenyamanan hidup manusia.

5. Politik/hukum, secara umum kondisi politik dan hokum di kabupaten Gowa aman dan terkendali dengan melihat melihat tingkat krimihalitas yang rendah dengan rata rata tingkat penyelesaian perkara $3,4 \%$ perbulan.

6. Sosial Budaya, latar belakang masyarakat Kabupaten Gowa yang sangat kental dengan sejarah masa lalu sebagai kerajaan besar di Nusantara, memiliki peninggalan sejarah masa lalu dalam bentuk situs budaya dan nilai kepahlawanan Sultan Hasanuddin dan Syech Yusuf yang menjadi asset Kabupaten gowa dalam meningkatkan perekonomian seperti kunjungan wisatawan baik Nusantara maupun dari Manca Negara.

\section{Karakteristik Pengangguran}

Jumlah penganggur di Kabupaten Gowa mengalami penurunan dari tahun sebelumnya, dimana tahun 2017 jumlah penganggur sebanyak $20.453(6,14 \%)$ turun menjadi $14.650(4,80 \%)$.

\section{Karakteristik Kinerja UMKM}

UMKM di Kabupaten Gowa mengalami peningkatan dari jumlah 6.297 unit pada tahun 2017 menjadi 6.926 unit pada tahun 2018, dari jumlah tersebut ada 3 (tiga) sector yang mendominasi UMKM di Kabupaten Gowa, Yakni : Perdagangan, Jasa dan Produksi 


\section{KESIMPULAN}

1. Karakteristik Sumber Daya Manusia yang dimiliki Kabupaten Gowa memiliki hubungan dan pengaruh terhadap menurunnya jumlah pengangguran dan berpengaruh terhadap pertumbuhan UMKM.

2. Karakteristik Lingkungan yang dimiliki Kabupaten Gowa memiliki hubungan dan pengaruh terhadap menurunnya jumlah pengangguran dan berpenganuh terhadap pertumbuhan UMKM.

3. Dengan meningkatnya pertumbuhan UMKM di Kabupaten Gowa, maka secara keseluruhan laju perekonomian meningkat.

\section{DAFTAR PUSTAKA}

Sukirno, Sadono. 2000. Makro Ekonomi Modern. Penerbit PT. Raja Grafindo Perkasa, Jakarta.

Anoraga Pandji, 2004. Manajemen Bisnis, Cetakan Ketiga. Rineka Cipta, Jakarta.

James A.F. Stoner ... [et al.] Stoner, James A. F. (James Arthur Finch), ...Englewood Cliffs, N.J. : Prentice Hall, 1995 , Management, English Book; Illustrated, 8. 